\title{
Література
}

1. Артемова Л. В. Історія педагогіки України : [підруч. для студ. вищ. пед. навч. закл.] / Любов Вікторівна Артемова. - К. : Либідь, 2006. - 424 с.

2. Барбашова I. А. Загальна характеристика сенсорного розвитку в молодшому шкільному віці / I. А. Барбашова // Педагогічний дискурс : [3б. наук. праць / гол. ред. I. М. Щоробура]. - Хмельницький : Балюк І. Б., 2011. - Вип. 10. - С. 33-39.

3. Джуринский А. Н. История педагогики : [учеб. пособ. для студ. педвузов]/ Александр Наумович Джуринский. - М. : ВЛАДОС, 2000. - 432 с.

4. Зайченко І. В. Історія педагогіки : [навч. посіб. для студ. вищ. навч. закл.] : у 2 кн. / Іван Васильович Зайченко. - К. : Слово, 2010. - Кн. I : Історія зарубіжної педагогіки. 2010. $-624 \mathrm{c}$.

5. Зайченко I. В. Історія педагогіки : [навч. посіб. для студ. вищ. навч. закл.] : у 2 кн. / Іван Васильович Зайченко. - К. : Слово, 2010. - Кн. II : Школа, освіта і педагогічна думка в Україні. - 2010. - 1032 с.

6. Коваленко С. І. Історія зарубіжної педагогіки. Хрестоматія : [навч. посіб.] / Є. І. Коваленко, Н. І. Бєлкіна; заг. ред. С. І. Коваленко. - К. : Центр навчальної літератури, 2006. $-664 \mathrm{c}$.

7. Левківський М. В. Історія педагогіки : [навч. посіб.] / Михайло Васильович Левківський. - [4-те вид.]. - К. : Центр учбової літератури, 2011. - 190 с.

Стаття надійшла до редакції 27.05.2012 р.

\section{ВИВЧЕННЯ ПРОБЛЕМИ СПОЖИВЧОЇ КУЛЬТУРИ МАЙБУТНІХ УЧИТЕЛІВ ТЕХНОЛОГІЧНОЇ ОСВІТИ}

Вовк Н. В. Вивчення проблеми споживчої культури майбутніх учителів технологічної освіти.

У статті розглянуто питання вивчення проблеми формування споживчої культури майбутніх учителів технологічної освіти, визначено рівні та показники споживчої культури студентів. Культура споживання - ие сукупність стійких форм соиіальної взаємодї, закріплених у нормах і иінностях, засоби комунікації, які часто передаються від покоління до покоління. Вона виявлясться в існуванні відносно стійких форм, моделей споживання.

Ключові слова: культура, культура споживання.

Вовк Н. В. Изучение проблемы потребительской культуры будущих учителей технологического образования.

В статье рассмотрены вопросы изучения проблемы формирования потребительской культуры будущих учителей технологического образования, определены уровни и показатели потребительской культуры студентов. Культура потребления - это совокупность стойких форм соииального взаимодействия, закрепленных в нормах и иенностях, средства коммуникации, которые часто передаются от поколения к поколению. Она проявляется в существовании относительно стойких форм, моделей потребления.

Ключевые слова: культура, культура потребления.

Vovk N. A case study of consumer culture of the future teachers of technology education.

In article questions of studying of a problem of formation of consumer culture of future teachers of technological education are considered, levels and indicators of consumer culture of students are defined. The culture of consumption is a set of resistant forms of the social interaction fixed in norms and values, means of communication which are often transferred from generation to generation. It is shown in existence of rather resistant forms, consumption models.

Key words: culture, culture of consumption. 
Постановка проблеми. Вища школа - основний соціальний інститут, за допомогою якого суспільство може розв'язувати завдання формування рівня соціальної зрілості особистості, достатнього для забезпечення іiі незалежності, самостійності у розв'язанні значущих проблем в різних сферах життедіяльності, а також сприяє розвитку базової культури студентів, важливою складовою якої є споживча культура. Саме вона відіграє велику роль у загальній культурі особистості і впливає на розвиток всіх іiі компонентів. Актуальність теми полягає в тому, що в умовах глобального поширення масової культури, ключовими цінностями якої є розваги та споживання, необхідно спрямовувати молоде покоління на чітке формування в студентів соціально значущих цінностей, знань, норм і зразків поведінки, розумного поєднання у споживанні матеріального і духовного, що має стати цілеспрямованим і систематичним педагогічним процесом.

Аналіз спеціальної літератури показав, що проблема формування споживчої культури студентів у теорії і практиці педагогіки не отримала достатнього висвітлення. Між тим, досліджувана проблема різноманітна $\mathrm{i}$ складна. Вимагається науково обгрунтоване виокремлення теоретикометодологічних основ формування споживчої культури, розгляд специфіки педагогічних умов, засобів, форм і методів навчання.

Останні публікації. Проблема поведінки та розвитку споживчої культури є багатогранною. 3 позиції психології, філософії та педагогіки нею займалось багато науковців, а саме: В. М'ясищев, Д. Кікнадзе, В. Радаєв, П. Фресс та Ж. Піаже, А. Леонтьєв, А. Здравомислов, Т. Марченко, Ю. Резник, Е. Смирнов, А. Абрамова, Ю. Васильєв, Л. Кураков, А. Нісімчук, І. Сасова, Н. Хроменков, Ю. Шаронін, Б. Шемякін, А. Шпак. Проблемам соціалізації молоді, молодіжної культури присвячено дослідження В. Воробйова, О. Волжиніна, І. Дементьєвої, Л. Карцева, П. Козирьова та багатьох інших. Вони розглядали ідею формування споживчої культури особистості як один із аспектів оволодіння вищою освітою та розвитку базової культури людини, відображенням якої є перехід до особистісно орієнтованого утворення, яке забезпечує єдність і зв'язок духовного та соціокультурного простору, оволодіння знаннями, вміннями та навичками, розробку дидактичної системи, спрямованої на досягнення загальної мети діяльності вищої школи як соціального інституту.

Мета статі. Вивчення проблеми формування споживчої культури майбутніх учителів технологічної освіти, визначити рівні та показники споживчої культури студентів.

Отримані результати. Перші спроби розроблення теорії споживання пов'язані з цілою низкою ключових фігур суспільствознавства XIX-XX століть. Саме класики соціології - М. Вебер, Т. Веблен, Г. Зіммель та інші - подають у своїх роботах теоретичне обгрунтування процесів, що відбувалися в галузі споживання в період з XVIII по XIX століття, розкриваючи деякі основні поняття, пов'язані з цим явищем. 
Американець T. Веблен, наприклад, наприкінці XIX ст. запропонував теорію престижного споживання. Німецький соціолог Г. Зіммель висунув низку ключових ідей теорії моди. Він звернув увагу на те, що мода, по суті, має класовий характер, будучи засобом вираження і встановлення статусних відмінностей [4, с.205].

Німецький соціолог і економіст В. Зомбарт запропонував концепцію розкоші. Інший німецький соціолог М. Вебер формулював концепцію статусних груп і протестантської етики. Ці імена часто цитуються в дослідженнях $з$ проблеми споживання [2].

Особливості етапу, пов'язаного 3 розвитком масового виробництва i масового споживання в першій половині XX століття відображені у виниклих в 1950-1960-ті рр. в західній науці концепціях «суспільства споживання», авторами яких є найбільші соціологи: У. Ростоу, Ж. Форрест, Р. Арон, Дж. Гелбрейт. Характер споживання описується у роботах ряду інших відомих вчених: Ж. Бодріяра, П. Бурдьє, Д. Ліона, С. Майлза, М. Фезерстоуна, Е. Фромма та інших. Багато хто з них вказують на небезпеки, що криються в посиленні тенденції до споживання. Більшість авторів зауважують, що в постсучасному суспільстві посилюється символічна функція споживання. Споживання стає свого роду ланкою, частиною більш широкого символічного обміну, до якого залучено всі члени суспільства.

На думку Ж. Бодріяр, предметом розгляду є знакове споживання, що є кодом, мовою спілкування між людьми. Ж. Бодріяр визначає споживання як соціальний процес, основний у соціокультурній діяльності сучасного суспільства. У суспільстві споживання використання речей не вичерпується їх простим практичним застосуванням (яке мало місце завжди й усюди) або навіть їх семіотичним застосуванням як знаків відмінності, багатства, престижу тощо (що теж спостерігається в усіх людських суспільствах) [1, с.21].

Споживацтво підвищує значимість споживання в повсякденному житті людей, споживання стає для людини одним зі способів конструювання свого «Я», і в якості одного 3 найважливіших мотивів споживання є прагнення людини до самореалізації, самоактуалізації.

Різноманітні проблеми споживання, споживчої поведінки знайшли відображення у працях сучасних українських соціологів Е. Донченко, Ю. Пачковського, Л. Сорокіної, О. Щерби - здійснює аналіз мотиваційних теорій особистості в процесі споживання. Порушує питання про неадаптованість західної реклами до українських реалій і наголошує на тому, що необхідним $є$ вивчення регіональних відмінностей споживачів. Розглядає особливості символів та гендерного аспекту, відображених у національному рекламному продукті.

Також звертають увагу на важливість формування споживчої культури в Україні, проблеми споживання, споживчої поведінки у своїх працях: В. Пилипенко, С. Скибинський, В. Рєзник. Отже, у сучасній українській соціології культура споживання $\epsilon$ не достатньо вивченою галуззю. У соціології культура споживання розглядається як соціальний феномен, так $\mathrm{i}$ 
сфера соціалізації особистості, формування соціальних норм, цінностей, у якій фокусуються взаємовідносини між людьми, саме тому вона привертає увагу соціологів.

Споживання стає свого роду ланкою, частиною більш широкого символічного обміну, до якого залучені всі члени суспільства.

Концепт «споживання» містить багато положень властивих соціологічним теоріям споживання, він $є$ певним початком, що $є$ носієм різноманітних форм майбутньої організації, полем перетину форм шляхів розвитку суспільства, стосунків між людьми.

У людському суспільстві споживання перебуває в тісних взаємозв'язках із культурою. Деякі автори заявили про «моралізацію ринків», маючи на увазі, що виробники й споживачі - основні учасники ринку - приділяють усе більше уваги іншим чинникам, окрім одержання вигоди. Важливо зрозуміти, що споживання нині, в умовах постіндустріального суспільства, пов'язано не стільки 3 багатством і розкішшю, скільки 3 соціальною конструкцією ідентичності людини, з тим, як він створює образ самого себе. Споживання, що привертає увагу навколишніх, яке розцінюється як сигнал про здібності людини, нагадує класичну дилему ув'язненого. Щоб справити добре враження, недостатньо одягнути чистий і добре зшитий костюм. Варто придбати щось більш ефектне, ніж те, що носять інші. Це стимулює кожного менше заощаджувати і більше витрачати на одяг. Унаслідок цього споживання, що привертає увагу, буде, по суті, характеристикою місця, яке людина займає в суспільстві. У недалекі часи промислових революцій, коли відбулися принципові зміни у світі речей (поділ праці, поява мануфактури i перших машин i, отже, серійного виробництва), людина увірувала, що порятунок у праці та накопичених результатах цієї праці. В індустріальному суспільстві з'явилася ідея прогресу - ідея розвитку від простого до складного, від поганого до хорошого. Прогрес в уявленні, що майбутнє краще за сьогодення.

Важливим для нашого дослідження $є$ висновок про необхідність організації процесу навчання, що сприяє стимулюванню та активізації змісту і методів навчання, що полягає в їх спрямованості до особистості учня, до його життєвих інтересів і потреб, його почуттів, його власного життєвого досвіду.

Задля виявлення обізнаності студентів у розуміння споживчої культури нами було обрано метод бесіди. Під час неї ми спілкувались за студентами, ставили запитання які безпосередньо нас цікавили. Наприклад, чи розуміють вони, що передбачає споживча культура, які конкретні соціальні вияви вона має, що наразі головним серед потреб є у їхньому житті.

На підставі цього, для остаточного висновку та закріплення отриманих результатів ми вирішили використати метод тестування, що містило основні ключові питання, які б змогли дати вичерпну відповідь на стан проблеми розвитку та становлення «споживчої культури» 3-поміж студентів. Студентів II курсу ми віднесли до контрольної групи, та студентів IV до експериментальної. Рівень аналізу показників унаочнено в таблиці 1. 
Таблиияя 1

Визначення рівня та показників споживчої культури студентів

\begin{tabular}{|c|c|}
\hline Рівень & Бали \\
\hline Високий & $9-11$ відповідей \\
\hline Середній & $6-8$ відповідей \\
\hline Низький & $1-5$ відповідей \\
\hline
\end{tabular}

\begin{tabular}{|c|l|}
\hline Рівень & \multicolumn{1}{|c|}{ Показники } \\
\hline Високий & $\begin{array}{l}\text { Високому рівню споживчих знань відповідає активне володіння } \\
\text { споживчими знаннями, необхідний і достатній обсяг і системність } \\
\text { споживчих знань, розуміння того, які критерії містить «споживча культура». }\end{array}$ \\
\hline Середній & $\begin{array}{l}\text { Середній рівень характеризує пасивне володіння споживчими знаннями і } \\
\text { ситуативне їх застосування. }\end{array}$ \\
\hline Низький & $\begin{array}{l}\text { Низький - відсутність у студента споживчих знань, розуміння «споживчої } \\
\text { культури». }\end{array}$ \\
\hline
\end{tabular}

Результати дослідження за критерієм відносний рівень «споживчої культури» студентів:

\section{Порівняльні таблиці споживчої культури студентів II та IV курсу}

Таблиия 2

\begin{tabular}{|c|c|c|c|}
\hline \multicolumn{4}{|c|}{ ІІ Курс, контрольна група } \\
\hline \multirow{2}{*}{ Рівень } & Хлопці & \multirow{2}{*}{$\%$} \\
\cline { 2 - 3 } & 1 & 1 & 7 \\
\hline Високий & 3 & 5 & 30 \\
\hline Середній & 10 & 7 & 63 \\
\hline Низький & \multicolumn{2}{|c|}{ Дівчата } & студентів \\
\hline
\end{tabular}

\begin{tabular}{|c|c|c|c|}
\hline \multicolumn{3}{|c|}{ IV Курс, експериментальна група } & \multirow{2}{*}{$\%$} \\
\cline { 2 - 3 } & \multicolumn{2}{|c|}{ Кількість студентів } & 10 \\
\hline \multirow{2}{*}{ Рівень } & Хлопці & Дівчата & 23 \\
\hline Високий & 1 & 5 & 67 \\
\hline Середній & 2 & 9 & 2 \\
\hline Низький & 11 & 5 &
\end{tabular}

Отже, аналізуючи отримані результати можна стверджувати, що рівень «споживчої культури», розуміння цього поняття студентами як другого так $\mathrm{i}$ четвертого курсу майже тотожне. На запитання анкети з кожного курсу, як в хлопців так і в дівчат дуже малий відсоток отримав високий рівень, небагато студентів отримали - середній рівень і значна кількість - низький. Тому результати тестування доводять необхідність підвищення споживчої культури 3-поміж студентів за рахунок впровадження нового курсу, присвяченого розвитку «споживчої культури», нових методик навчання, форм і засобів організації навчального процесу.

Висновки. Культура споживання визначає набори зразків споживання, виборів, цінностей і смаків, які допомагають людині орієнтуватися в 
соціальному просторі. Це також надіндивідуальна реальність, яка створюється людьми як безпосередньо, так i за допомогою соціальних інститутів - держави, бізнесу, церкви тощо. Сучасність зумовлюється необхідністю приділити особливу увагу детермінантам споживання в контексті формування соціального спрямування сучасних суспільств, ролі держави у формуванні сучасної споживацької культури в розвинених країнах світу та в Україні.

Соціально-економічний прогрес суспільства яскраво виявляється в дії закону зростання кількості потреб. Цей закон ілюструє об'єктивну (незалежну від волі і бажання людей) необхідність зростання й удосконалення людських потреб, пов'язаних із розвитком виробництва i культури. Проте посилення потреб не полягає в простому пропорційному зростанні всіх їх видів. Передовсім задовольняються і мають певну межу розвитку потреби низького порядку. Навпаки, по суті безмежними є запити вищого порядку - соціальні й інтелектуальні. Подальшу свою роботу вважаємо у розробленні завдань із формування споживчої культури майбутніх учителів технології.

\section{Лiтература}

1. Глазиріна В. М. Методологічні негаразди соціальної педагогіки / Валентина Михайлівна Глазиріна. - Донецьк : ДонНУ, - 2003. - 221 с.

2. Іонін Л. Г. Соціологія культури / Леонід Григорович Іонін. - М. : Думка, 1996. - 173 с.

3. Кикнадзе Д. О. Потреби, поведінка, виховання / Дмитро Олекійович Кикнадзе. М. : Думка, 1968. - 278 с.

4. Ядгаров Я. С. Історія економічних вчень / Ярослав Сергійович Ядгаров. - М. : Освіта, 1996. - 361 с.

Стаття надійшла до редакції 29.05.2012 р.

УДК 74.213 .51

Ю. В. Недашковський, кандидат техн. наук, доцент,

O. I. Кучма,

кандидат техн. наук, доцент,

Криворізький педагогічний інститут

ДВНЗ «Криворізький наияіональний університет»

\section{АКТУАЛЬНІ ПИТАННЯ ПОЛІТЕХНІЧНОЇ ПІДГОТОВКИ ВЧИТЕЛІВ ТРУДОВОГО НАВЧАННЯ}

Недашковський Ю. В., Кучма О. І. Актуальні питання політехнічної підготовки вчителів трудового навчання.

Розкрито деякі аспекти політехнічної підготовки вчителів трудового навчання в частині використання міжпредметних зв'язків $і$ комп'ютерних технологій.

Ключові слова: комп'ютерні технології, інструментарій, технічні дисципліни, міжпредметні знання, креслення.

Недашковский Ю. В., Кучма А. И. Актуальные вопросы политехнической подготовки учителей трудового обучения.

Приведены некоторые аспекты политехнической подготовки учителей труда в части использования межпредметных связей и компьютерных технологий. 